\title{
The Consequence of work environment on Employees Productivity
}

\author{
Dr. Aram Hanna Massoudi, Dr. Samir Salah Aldin Hamdi \\ College of Administrative and Financial Science/ Cihan University/Erbil, Iraq
}

\begin{abstract}
This research aims to analyze working environment of a foreign private banks operating in Kurdistan Region of Iraq and examines the relationship between the workplace physical conditions and employee's productivity. The research uses qualitative approach, the data was collected from a questionnaire distributed to 50 employees working in four foreign banks in the Kurdistan Region of Iraq.The result will show that There is a relationship between office environment and productivity of employees. Behavioral components of office environment have a greater effect on productivity, than the physical components alone. And Satisfaction of Employees towards overall Workplace Environment leads to productivity.
\end{abstract}

Keywords: Workplace environment, Productivity.

\section{Introduction}

Organizational environment plays a essential role for the employees. These days employees may have a large number of working alternatives, thus the environment in workplace becomes a critical factor for accepting and/or keeping the jobs. The quality of environment in the workplace may simply determine the level of employee's motivation, subsequent performance and productivity. How well employees get along with the organization influence the employee's error rate, level of innovation and collaboration with other employees, absenteeism and ultimately time period to stay in the job. Therefore, HR managers need to consider new strategies for selecting and retaining best talents for their organizations. Higher salaries and compensation benefits may seem the most likely way to attract employees. However, quality of the physical workplace environment may also have a strong influence on a company's ability to recruit and retain talented people. Some factors in workplace environment may be considered essential such as employee's engagement, productivity, morale, comfort level etc. both positively and negatively.

Although convenient workplace conditions are requirements for improving productivity and quality of outcomes, working conditions in many organizations may present lack of safety, health and comfort issues such as improper lightening and ventilation, excessive noise and emergency excess. People working under inconvenient conditions may end up with low performance and face occupational health diseases causing high absenteeism and turnover. There are many organizations in which employees encounter with working conditions problems related to environmental and physical factors. Pech and Slade (2006) argued that the employee disengagement is increasing and it becomes more important to make workplaces that positively influence workforce. According to Pech and Slade the focus is on symptoms of disengagement such as distraction, lack of interest, poor decisions and high absence, rather than the root causes.

The research presents the analysis of the working environment of a four private foreign bank in Kurdistan Region of Iraq. The objective of this research is to investigate if there exists any relation between workplace conditions and employee's performance. A survey study is implemented on the employees of the bank.

\subsection{Research Problem:}

Many organizations have been trying new designs and techniques to construct office buildings, which can increase productivity, and attract more employees. Many authors have noted that, the physical layout of the workspace, along with efficient management processes, is playing a major role in boosting employees' productivity and improving organizational performance. Other factors are also significant such as: furniture, noise, flexibility, comfort, communication, lighting, temperature and the air quality. This research is investigating dimensions of workplace environment in terms of physical as well as behavioral components. Therefore the researchers present the following related questions:

1. Is there any relationship between the components of office environment and the performance level of employees?

2. Which component of office environment? Behavioral or physical has the greater impact on productivity of the employees.

3. Which elements of the two components of the office environment have the significant effect on the performance level of employees? 
1.2 Research Objectives: The objectives of this research are:

2. to investigate if there exists any relation between workplace conditions and employee's performance.

3. To develop an understanding for describing importance of work place environment in the organizations.

4. To describe the factors that develop work place environment and impact positively on employees productivity

5. To explain results for validating the proposed frame work.

\subsection{Research Importance}

1. Introducing workplace environment as one of the important issues for employees performance and happiness at work,

2. Shedding the spotlight on productivity and the factors that affect it.

3. Give general ideas for managers of organization in the Region of Kurdistan about workplace design and its importance for productive workforce.

4. This research could be of help to all administrative staff in the region also it can help business student to understand the subject.

5. Enriching the local library with extra reference to help student and scholars in business researches.

1.4 Research Hypothesis: This research study explores the following research hypothesis.

H0: There is no relationship between office environment and productivity of the employees.

$\mathrm{H} 1$ : There is a relationship between office environment and productivity of employees.

$\mathrm{H} 2$ : Behavioral components of office environment have a greater effect on productivity, than the physical components alone.

H3: Satisfaction of Employees towards overall Workplace Environment leads to productivity.

1.5 Research Methods: This research depended on qualitative approach based on both primary and secondary data. A survey has been implemented in order to test the hypothesis.

The primary data was collected through a questionnaire, it has 3 sections with 13 questions. In the first part; demographic information is gathered from the 50 employees who answered the questionnaire. Their gender, age, education profile and seniority are asked in the first 4 questions. In the second part, attendees gave their evaluations whether workplace environment has a real effect on their productivity level. In this part their evaluations regarding physical factors are asked directly but behavioral components are asked indirectly in order to minimize their perception. Since behavioral factors are subjective factors, questions regarding behavioral factors are allocated more than one question. The secondary data was collected from textbooks, scientific articles, journals, and websites.

1.6 Research Sample: The population of this research is four private foreign banks operating in Kurdistan Region of Iraq; these banks are: Byblos Bank S.A.L. - Iraq Branches, Fransabank Erbil, Credit Libanais, BankMed. The research sample is 50 employees working in the front offices in those banks.

\subsection{Workplace environment:}

\section{Literature Review}

Many executives are under the mistaken impression that the level of employee performance on the job is proportional to the size of the employee's compensation package. Although compensation package is one of the extrinsic motivation tool (Ryan and Deci, 2000) it has a limited short term effect on employees' performance. A widely accepted assumption is that better workplace environment motivates employees and produces better results. Office environment can be described in terms of physical and behavioral components. These components can further be divided in the form of different independent variables. An organization's physical environment and its design and layout can affect employee behavior in the workplace. Brill (1992) estimates that improvements in the physical design of the workplace may result in a 5-10 percent increase in employee productivity. He argued that increasing the organization's physical layout is designed around employee needs in order to maximize productivity and satisfaction.

\subsubsection{Definition of workplace environment:}

Location where a task is completed. When pertaining to a place of employment, the work environment involves the physical geographical location as well as the immediate surroundings of the workplace, such as a construction site or office building. Typically involves other factors relating to the place of employment, such as the quality of the air, noise level, and additional perks and benefits of employment such as free child care or unlimited coffee, or adequate parking (www.businessdictionary.com). 
Also, the term work environment is used to describe the surrounding conditions in which an employee operates. The work environment can be composed of physical conditions, such as office temperature, or equipment, such as personal computers. It can also be related to factors such as work processes or procedures.

\subsubsection{Physical components of Workplace environment:}

Temperature: Companies should maintain an appropriate temperature for employees. Although most people have their own preferences for hot and cold temperatures, an unpleasant setting may cause workers to perform poorly on the job. When work is performed outdoors, employers must take into account how long the employee will be exposed to direct sunlight, rain or snow. Adequate provisions must be in place to reduce the harmful effects of working in extreme conditions.

Lighting: Without proper lighting, people may strain to view objects, which can lead to eye fatigue. This is especially important for those who use a computer frequently to perform work-related tasks. When viewing contrasts between dark and light areas of a computer screen, people can experience headaches. Companies can improve a poor lighting situation by using light diffusers and drapes to cover windows.

Heavy Lifting: Repetitive heavy lifting increases the chances of injury. Proper lifting techniques must be practiced. Bursitis and spinal disc herniation are just a couple of the disorders that can result from poor lifting technique. Employers can use materials and equipment that make the process of lifting objects easier. Properly training employees about lifting safely can mitigate negative impacts from this physical work environment factor.

Noise: Increased levels of noise in the workplace can cause employees to endure stress and fatigue. To control noise in an area, carpeting is recommended.Hard surfaces act to reflect noise and boosts the volume of anything striking those surfaces in an office. Office machines can also contribute to high noise levels. Barriers that absorb sounds can help control this. The ideal sound range for office work varies between 55 to 65 decibels.

2.1.3 Behavioral components of workplace environment: Aside from the job scope itself, one factor that significantly influences how employees feel about work is the environment. By work environment, It means everything that forms part of employees' involvement with the work itself, such as the relationship with coworkers and supervisors, organizational culture, room for personal development, etc. A positive work environment makes employees feel good about coming to work, and this provides the motivation to sustain them throughout the day. If you're looking for a new job, then we would say that assessing the work environment is a crucial step you shouldn't skip. After all, this is the place you might be working at in future and you wouldn't want to be dragging yourself to work every single morning!

\section{Transparent \& Open Communication:}

In essence, a transparent and open form of communication addresses the employee's need to feel that what they have to say has value. It is what makes employees feel that they belong in the organization. Work then becomes meaningful because the employees know that what they contribute affects the organization that they are affiliated with. It is thus essential for staff to discuss the organization's philosophy, mission and values, from time to time during retreats, meetings, etc to ensure that everyone knows what they're working for other than their paychecks. Having open discussions get people involved and allow them to share their views and perspectives on how to achieve company goals. After which, the management side will give their own perspectives on how to fulfill the organization's mission (www.hongkiat.com).

2. Work-Life Balance: There has to be some sort of balance between work and personal life. In general, having that sense of balance will improve job satisfaction among employees because they will feel that they're not overlooking the other areas of their lives that are, if not more, important to them than work. When employees fulfill their various needs and goals in life, such as those of family, friends, spiritual pursuits, selfgrowth, etc, they can then feel more confident about themselves and perform their best at work. Apart from that, employees that are exposed to more experiences in life outside of work can use what they've gained and apply that to their work. In other words, work-life balance can promote creativity and out-of-the-box thinking.

3. Training \& Development-Focused: In a time when change is more rampant than ever before, it is necessary for organizations to be keep abreast with the changes and train their employees accordingly. For instance, technology is evolving so rapidly that what organizations commonly used ten years ago could be made obsolete today (e.g. Zip drives, dial-up modems, etc). Adapting to change is never more crucial in this era because those who don't, get replaced. This applies to both the individual and the organization itself. A training and development-focused organization has a clear roadmap for training their employees to sustain and enhance the productivity of the organization as a whole. Essentially speaking, there are two kinds of skills that can be developed: hard skills and soft skills (www.hongkiat.com).

4. Recognition for Hard Work: Rewards are necessary to encourage certain behaviors in persons. This is known as positive reinforcement under operant conditioning in the field of psychology. It is used in organizational behavior management as well: by rewarding employees who put in effort for their work, this will promote similar behaviors in the future. A reward here doesn't have to be monetary in nature; sometimes even a 
simple verbal recognition by the supervisor is all that is necessary to spur the employees' motivation. When hard work is appropriately rewarded and duly recognized by the management, employees will naturally feel valued by the organization for what they put in. Such mentality is healthy for the organization because employees will be willing to go the extra mile without worrying about not getting anything in return (www.hongkiat.com).

5. Strong Team Spirit: As social beings, we naturally seek support from our peers and seek to belong to a group. Come tough times, the team should come together to deal with whatever problems are out there. This is where a sense of unity is evoked in the team and employees will no longer just feel that they're working for themselves. They are now working towards something bigger than themselves, and as a team (www.hongkiat.com).

2.2 Employee productivity: Employee productivity (sometimes referred to as workforce productivity) is an assessment of the efficiency of a worker or group of workers (whatis.techtarget.com). Productivity may be evaluated in terms of the output of an employee in a specific period of time. Typically, the productivity of a given worker will be assessed relative to an average for employees doing similar work. Because much of the success of any organization relies upon the productivity of its workforce, employee productivity is an important consideration for businesses.

2.2.1 Factors affect productivity: Employees are at their desks for an average of about five hours every day, and companies are paying for that time. But often the results of an employee's work vs. time spent don't exactly match up. A model employee that seems perfectly productive can turn out to be one of the worst offenders.

We recently came across a survey conducted by Deloitte, which indicates that companies are beginning to realize this and are starting to allocate resources for performance management, which focuses on the performance of employees and ensuring their output aligns with the company's goals. Within the report, analysts explain that last year, only 8 percent of their survey respondents believed their performance management process drove business value. "This year, the importance of performance management rose significantly, with 75 percent of respondents rating it an 'important' or 'very important' issue, up from 68 percent last year." (www.entrepreneur.com).

1. Goal setting is an important tool to attract motivation of the employee. There are two important purposes of goals in organizations are to guide the behavior of individuals and to motivate them to perform at higher levels of effectiveness (Richards, 1978). Specific goals are more effective than generalized goals that difficult goals lead to greater performance than do easy goals, as long as the goals are accepted (Erez et al, 1985), and that frequent, relevant feedback is important for goal setting effectiveness (Latham and Yukl, 1975). Effective goals, those with the above characteristics, are likely to promote a greater frequency of the work style behaviors. They help generate commitment, both to the goals and to the organization, which results in people doing more than they are required to do (Morrisey, 1977). Open communication is encouraged by the existence of effective goals. Members in groups with clear goals are more likely to communicate openly than those with unclear goals (Kiesler, 1978).

2. Performance Feedback is an information exchange and conflict resolution process between the employee and supervisor. While the supervisor gives his/her feedback and requirements, the employee enables to give his her feedback regarding his/her requirements. Although this process is formal, it could be managed informally by gaining closer relations for two sides (Chandrasekar, 2011). Each employee has a role in the organization. These roles are explained in Job Descriptions forms in a formal way. Employees' roles and task should be allocated consistently by his / her supervisor (Chandrasekar, 2011) which is defined as role congruity.

3. Defined Processes is the organization's responsibility to explain the workflow through documenting and communicating (Chandrasekar, 2011). The organization should find out tools what motivates its employees and has set up formal and informal structures for rewarding employees that behave in the way required. Rewards may consist of a mix of internal rewards, such as challenging assignments, and external rewards, such as higher compensation and peer recognition (Chandrasekar, 2011). This rewarding explains workplace incentives.

4. Supervisor support is crucial for employees to complete the job. Supervisors' interpersonal role is important to encourage positive relations and increase self-confidence of the employee. (Chandrasekar, 2011). Skilled and respected people are available to employees to help them to perform better in their current role and to assist them develop further into a future role. Chandrasekar (2011) defines the situation as mentoring/coaching. Time and material resources should be available to employees, enabling them to perform to the best of their ability.

\section{Empirical Study}

This research focuses on the relation between workplace conditions and employee's performance. The research is investigated dimensions of workplace environment in terms of physical as well as behavioral 
components. The analysis is implemented to a private foreign bank in Kurdistan Region of Iraq which has been operating for years in the region and offering many financial services for local consumers.

3.1 Data Collection A questionnaire has been implemented in order to test the hypothesis. The survey has 3 sections with 13 questions. In the first part; demographic information is gathered from the 50 employees who answered the questionnaire. Their gender, age, education profile and seniority are asked in the first 5 questions. In the second part, attendees gave their evaluations whether workplace environment has a real effect on their productivity level. In this part their evaluations regarding physical factors are asked directly but behavioral components are asked indirectly in order to minimize their perception. Since behavioral factors are subjective factors, questions regarding behavioral factors are allocated more than one question. Finally in the last part of the survey, attendees give points to the factors both physical and behavioral in order to rank the factors within each other.

3.1 Data Analysis: This section briefly discusses the survey results. The first section of the survey searches the demographic information on the survey attendees.

Section I: Demographic Information

The gender of this sample size is approximately in the middle of female and male. $\% 84$ of the attendees is between 20 to 39 years old. \%84 of the employees have at least undergraduate degree and more than \% 90 of the employees have more than 1 year seniority within the bank.

\begin{tabular}{|l|c|c|}
\hline \multicolumn{3}{|c|}{ Table 1: Gender size } \\
\hline Gender size & Frequency & $\%$ \\
\hline Male & 31 & $62 \%$ \\
\hline Female & 19 & $38 \%$ \\
\hline Total & 50 & $100 \%$ \\
\hline
\end{tabular}

\begin{tabular}{|l|c|c|}
\hline \multicolumn{3}{|c|}{ Table 2: Age distribution } \\
\hline Age & Frequency & $\%$ \\
\hline $20-24$ & 4 & $8 \%$ \\
\hline $25-29$ & 26 & $52 \%$ \\
\hline $30-39$ & 12 & $24 \%$ \\
\hline 40 and over & 8 & $16 \%$ \\
\hline Total & 50 & $100 \%$ \\
\hline
\end{tabular}

\begin{tabular}{|l|c|c|}
\hline \multicolumn{3}{|c|}{ Table 3: Education Profile } \\
\hline \multicolumn{1}{|c|}{ Educational Profile } & Frequency & $\%$ \\
\hline High School & 6 & $12 \%$ \\
\hline Undergraduate Degree & 42 & $84 \%$ \\
\hline Master Degree & 2 & $4 \%$ \\
\hline Total & 50 & $100 \%$ \\
\hline
\end{tabular}

\begin{tabular}{|l|c|c|}
\hline \multicolumn{3}{|c|}{ Table 4: Work seniority } \\
\hline \multicolumn{1}{|c|}{ Work Seniority } & Frequency & $\%$ \\
\hline 0 to 1year & 10 & $20 \%$ \\
\hline 1 to 2years & 14 & $28 \%$ \\
\hline 2 to 4 years & 16 & $32 \%$ \\
\hline More than 4 years & 10 & $20 \%$ \\
\hline Total & 50 & $100 \%$ \\
\hline
\end{tabular}

Section II: Workplace Environment Factors

\begin{tabular}{|c|c|c|c|}
\hline \multicolumn{4}{|c|}{ Table 5: The effect of relations with Superiors at the } \\
Workplace for Productivity \\
\hline Score & Response & H/C & Percentage \\
\hline 1 & Strongly Agree & 45 & $90 \%$ \\
\hline 2 & Agree & 5 & $10 \%$ \\
\hline 3 & Neutral & 0 & $0 \%$ \\
\hline 4 & Disagree & 0 & $0 \%$ \\
\hline 5 & Strongly Disagree & 0 & $0 \%$ \\
\hline \multicolumn{2}{r}{ Total } & 50 & $100 \%$ \\
\hline
\end{tabular}

\begin{tabular}{|c|c|c|c|}
\hline \multicolumn{4}{|c|}{ Table 6: Fair Treatment at the Workplace: } \\
\hline Score & Response & H/C & Percentage \\
\hline 1 & Strongly Agree & 43 & $86 \%$ \\
\hline 2 & Agree & 7 & $14 \%$ \\
\hline 3 & Neutral & 0 & $0 \%$ \\
\hline 4 & Disagree & 0 & $0 \%$ \\
\hline 5 & Strongly Disagree & 0 & $0 \%$ \\
\hline & Total & 50 & $100 \%$ \\
& & & \\
\hline
\end{tabular}

A supervisor support is crucial for employees to complete the job. Furthermore, interpersonal role of the supervisor is important to encourage positive relations and increase self-confidence of the employee. $100 \%$ of survey attendees strongly agree that relations with superiors at the workplace affect their production. Feeling as treated fairly is important for all employees in the workplace. Fair treatment motivates all employees to do and develop their tasks with full of interest. Table 6 shows that $86 \%$ of employees strongly agree that fair treatment plays a crucial role in motivation.

\begin{tabular}{|c|c|c|c|}
\hline \multicolumn{4}{|c|}{ Table 7: Communication System at the Workplace: } \\
\hline Score & Response & $\mathbf{H} / \mathrm{C}$ & Percentage \\
\hline 1 & Strongly Agree & 42 & $84 \%$ \\
\hline 2 & Agree & 3 & $6 \%$ \\
\hline 3 & Neutral & 5 & $10 \%$ \\
\hline 4 & Disagree & 0 & $0 \%$ \\
\hline \multirow[t]{2}{*}{5} & Strongly Disagree & 0 & $0 \%$ \\
\hline & Total & 50 & $100 \%$ \\
\hline
\end{tabular}

\begin{tabular}{|c|c|c|c|}
\hline \multicolumn{4}{|c|}{$\begin{array}{c}\text { Table 8: Environmental Factors - Physical } \\
\text { Factors- are Conductive to Work: }\end{array}$} \\
\hline Score & Response & H/C & Percentage \\
\hline 1 & Strongly Agree & 29 & $58 \%$ \\
\hline 2 & Agree & 11 & $22 \%$ \\
\hline 3 & Neutral & 6 & $12 \%$ \\
\hline 4 & Disagree & 3 & $6 \%$ \\
\hline 5 & Strongly Disagree & 1 & $2 \%$ \\
\hline \multicolumn{4}{|c}{} \\
\hline
\end{tabular}


Communication promotes trust and loyalty among the employees and encourages better team work and relationship shows communication system at the workplace.84\% of employee strongly agree with the importance of the communication at the workplace. It is the responsibilities of the companies to provide safe, healthy, friendly working conditions. Besides this; lightning, ventilation, heating, ergonomics are crucial factors for employees $.58 \%$ of employees strongly agree that environmental factors are important for them. Majority of employees agree that there exists a strong relation between physical factors and motivation.

Section III: Influence of workplace environment on Employee's productivity

\begin{tabular}{|l|c|c|}
\hline \multicolumn{3}{|c|}{$\begin{array}{c}\text { Table 9: Behavioral Factors Affecting the } \\
\text { Employee's Productivity }\end{array}$} \\
\hline \multicolumn{1}{|c|}{ Factors } & Mean & Rank \\
\hline Interpersonal Relationships & 4,32 & 2 \\
\hline Emotional Factors & 4,76 & 1 \\
\hline Job Assignment & 4,26 & 3 \\
\hline Overtime Duty & 3,40 & 4 \\
\hline Extended Work & 2,48 & 5 \\
\hline
\end{tabular}

\begin{tabular}{|l|c|c|}
\hline \multicolumn{2}{|c|}{$\begin{array}{c}\text { Table 10: Physical Aspects Influencing Employee's } \\
\text { Performance at the Workplace }\end{array}$} \\
\hline \multicolumn{1}{|c|}{ Factors } & Mean & Rank \\
\hline Furniture & 3,42 & 1 \\
\hline Office Space & 3,26 & 2 \\
\hline Interior Design & 2,18 & 3 \\
\hline Storage for Material & 1,14 & 4 \\
\hline
\end{tabular}

Employee's attitude at the workplace is affected by factors like interpersonal relations, emotional factors, job assignment, overtime duty and extended work. The emotional factor is one of the leading factor that affect the employees' attitude with a mean of 4,76. Interpersonal relations is regarded second with mean of 4,32. Since interpersonal relations at workplace does not serve a critical role in development and maintenance of trust and positive feelings among employees in the organization. Furniture and furnishing is one of the leading physical aspects - comfort level - that influence the employee's performance at the workplace with mean value of 3,42. Majority of employees ensures in bank that good condition and proper furnishing should be maintained in order to make them feel sophisticated while they work.

The results show that furniture and furnishing is the most effective physical workplace environment factor which increases or decrease employee's performance. Office space is ranked as second leading physical aspect with mean of 3,26 by the employees. Employees ensure that poor arrangement of office space, wastes time and energy by failing to provide the means for effective work habits. Interior surface has been given third rank with mean of 2,18. Interior surface acts as practical, aesthetic and conductive to intended purposes such as raising productivity, improving life style employees. Since it is ranked by third it signifies that employees are comfortable with interior surface. Storage of materials has been given the lowest significance with the mean value of 1,14 . Adequate storage facilities for materials are provided by the bank in order to arrange the materials properly. Thus it has weaker influence on work performance. The physical layout of an office is extremely important when it comes to maximizing productivity. Table 11 shows the appraisements of employees towards to the importance of the space and facilities provided to do their job. $78 \%$ respondents are dissatisfied with the space and facilities.

\begin{tabular}{|c|c|c|c|}
\hline \multicolumn{4}{|c|}{$\begin{array}{l}\text { Table 11: Satisfaction of Employees towards the } \\
\text { Physical Factors Provided: }\end{array}$} \\
\hline Score & Response & $\mathrm{H} / \mathrm{C}$ & Percentage \\
\hline 1 & Strongly Agree & 1 & $2 \%$ \\
\hline 2 & Agree & 7 & $14 \%$ \\
\hline 3 & Neutral & 3 & $6 \%$ \\
\hline 4 & Disagree & 39 & $78 \%$ \\
\hline 5 & Strongly Disagree & 0 & $0 \%$ \\
\hline & Total & 50 & $100 \%$ \\
\hline
\end{tabular}

\begin{tabular}{|c|c|c|c|}
\hline \multicolumn{4}{|c|}{$\begin{array}{l}\text { Table 12: Satisfaction of Employees towards the } \\
\text { Behavioral Factors: }\end{array}$} \\
\hline Score & Response & \multicolumn{2}{|c|}{ Percentage } \\
\hline 1 & Strongly Agree & 32 & $64 \%$ \\
\hline 2 & Agree & 14 & $28 \%$ \\
\hline 3 & Neutral & 0 & $0 \%$ \\
\hline 4 & Disagree & 2 & $4 \%$ \\
\hline 5 & Strongly Disagree & 2 & $4 \%$ \\
\hline & Total & 50 & $100 \%$ \\
\hline
\end{tabular}

32 employees out of 50 with $64 \%$ agree that they are satisfied with the behavioral environmental factors which they face with in the workplace. Only $8 \%$ of the attendees give unfavorable answers to the question.

\begin{tabular}{|c|c|c|}
\hline \multicolumn{3}{|c|}{ Table 13: Satisfaction of Employees towards } \\
overall Workplace Environment
\end{tabular}

Overall satisfaction has been exhibited in Table 13. Only just $18 \%$ of employees are dissatisfied with the overall working conditions of the bank. $82 \%$ of the staff are happy to be a part of the company. 


\subsection{Testing the Hypothesis}

H0: There is no relationship between office environment and productivity of the employees: based on our analysis and responses of bank employees (table 8), we reject hypothesis null.

H1: There is a relationship between office environment and productivity of employees: Based on our analysis (table 8 ), $80 \%$ of respondents believe there is relation. Therefore, we accept hypothesis 1 .

H2: The behavioral components of office environment have a greater effect on productivity, than the physical components alone: according to our analysis table 6,7,9 illustrate that the majority of respondents agree that behavior components affect productivity thus, We accept hypothesis 2 .

H3: Satisfaction of Employees towards overall Workplace Environment leads to productivity: based on our respondents answers (table 13) $82 \%$ believe that satisfaction of work place lead to productivity, thus, we accept hypothesis 3 .

\section{Conclusion and Recommendations:}

The researchers investigated the role of workplace environment in terms of physical as well as behavioral components on employees productivity. The analysis is implemented to a four private foreign bank operating in the Kurdistan region of Iraq and came up with the following conclusions:

\subsection{Conclusion}

1. The outputs show that the gender of this sample size is approximately in the middle of female and male. $\% 84$ of the attendees are between 20 to 39 years old. \%84 of the employees have at least undergraduate degree and more than $\% 80$ of the employees have more than 1 year seniority within the bank.

2. The survey gives us some clues regarding the effects of environmental factors on employee's productivity from the employees' perceptions. Questions regarding relation

3. with the supervisors, fair treatment and communication within the bank are asked to the attendees in order to be ensure that behavioral environmental component are significant for them. Almost all the attendees give strongly agree replies that relation with the supervisors, fair treatment and communications is important.

4. Added to behavioral, also attendees evaluated the importance of physical factors. Surprisingly only $58 \%$ of employees give strongly agree replies to the question. It is the first clue that behavioral factor is more important than physical factors for the employees.

5. For the behavioral part emotional factors and relations are gotten the first two highest ranks. Comfort level of the offices is more important factor than the office lay out for the employees as physical environmental factors.

6. In this part of the survey, satisfaction of the employees' towards the physical and behavioral environmental factors is evaluated. Employees are not satisfied with the physical factors which the bank provided for them. But on the other hand, employees' satisfaction towards the behavioral environmental factors is remarkably high.

7. At the last question, overall satisfaction towards the workplace environment is asked to the employees, They give favorable results, almost all of them declared that they are satisfied with the workplace environment.

8. Finally, survey results show that while the employees are unhappy with the physical conditions of the workplace, they have remarkable satisfaction with the workplace by having strong behavioral workplace conditions.

According to the survey results it is proven that:

There is a relationship between office environment and productivity of employees.

Behavioral components of office environment have a greater effect on productivity, than the physical components alone.

Satisfaction of Employees towards overall Workplace Environment leads to productivity.

\subsection{Recommendations}

1. The results of this research depend on employees' perception which has been implemented in order to analysis the effects of workplace environment towards to employees' performance, Since there is no performance management measures in the bank, the real effects of workplace environment on employees' performance (productivity) could not be measured systematically.

2. In addition to this, 50 employees of the banks work in the same department when conducted the survey. Survey results could be altering if the survey would conduct to the other department's employees.

3. Also, the research could be extended by investigating the gender differences towards the effects of workplace environment and productivity. 


\section{References}

[1]. Brill, M. (1990). Workspace design and productivity. Journal of Healthcare Forum, 35 (5), pp. 51-3.

[2]. Chandrasekar. K. (2011). Workplace Environment and its Impact on Organizational Performance in Publc1 Sector Organizations, International Journal Of Enterprise Computing and Business Systems, Vol:1,Issue:1.

[3]. Dorgan, C.E. (1994) productivity Link to the Indoor Environment Estimated Relative to ASHRAE 62- 1989Proceedings of Health Buildings '94, Budapest, pp.461 472.

[4]. Erez, M., Earley, P. C. and Hulin, C. L. (1985). The impact of participation on goal acceptance and performance: A two step model. Academy of Management Journal, 28, 50-66.

[5]. (http://www.businessperform.com/workplace-training/workplace_environment.html. Retrieved March 3, 2016.

[6]. http://whatis.techtarget.com/definition/employee-productivity/. Retrieved February 21, 2016

[7]. http://www.businessdictionary.com/definition/work-environment.html\#ixzz439roBeNQ. Retrieved March 2, 2016.

[8]. http://www.entrepreneur.com/article/245644. Retrieved February 21, 2016.

[9]. http://www.hongkiat.com/blog/positive-working-environment. Retrieved February 13, 2016

[10]. Kiesler, S. (1978), Inter-personal Processes in Groups and Organizations, AHM Publishing, Arlington Heights, IL.

[11]. Latham, G. P. and Yukl, G. A. (1975). Assigned versus participative goal setting with educated and uneducated wood workers. Journal of Applied Psychology, 60, 299-302.

[12]. Morrisey, G.L. (1977), Management by Objectives and Results for Business and Industry, Addison-Wesley, Reading, MA.

[13]. Pech, S and Slade, M (2006). The role of environmental control on environmental satisfaction, communication, and psychological stress: effects of office ergonomics training. Environment and Behavior, 36(1), 617-638.

[14]. Richards, M.D. (1978), Organization Goal Structures, West Publishing, St Paul, MN

[15]. Rolloos, M. (1997), Organization Goal Structures, West Publishing, St Paul, MN.

[16]. Ryan, R. M., and Deci, E. L. (2000). Self-determination theory and the facilitation of intrinsic motivation, social development, and well-being. American Psychologist, 55, 68-78.

[17]. Sutermeister, R.A. (1976) People and Productivity, 3rd edition, New York.

[18]. Uzee, J (1999), the inclusive approach: creating a place where people want to work. Facility Management Journal of the International Facility Management Association 26-30. 